\title{
A CULTURA EM PROCESSO DE MUDANÇAS EXTREMAS
}

José Teixeira Coelho Neto

Primeiro eu gostaria de agradecer, Cristina, pelo convite para participar deste momento. Tomo como uma obrigação fazer publicamente uma homenagem muito pequena ao casal Guita e José Mindlin. Um casal que eu não consigo dividir, se penso na Guita penso no José, e vice-versa. Extremamente importantes para a cultura do país e desta cidade, dando um exemplo de desapego enorme. Acho que todos sabem que a biblioteca de ambos poderia ter ido para os Estados Unidos, como foram outras coleções de arte do Brasil. Não faço nenhuma crítica àquelas que se foram, porque sabemos, com provas, que estão sendo muito bem servidas lá fora e que estão servindo. Mas o casal Mindlin insistiu em deixar a biblioteca aqui, e a UsP recebeu este dom imenso. Carlos Augusto Calil elencou algumas qualidades da Guita, que poderiam ser também do José, e eu acrescentaria mais uma: a do humor. Estive presente à sessão de assinatura, não me lembro se do acordo de intenções entre o casal e a USP para a criação desta biblioteca, ou se já de fato do próprio acordo final. E o José fez um discurso curto naquela ocasião, que ficou gravado na minha memória. Ele disse que estava assinando apenas um contrato de comodato, de cessão temporária da coleção 
para USP por algo como noventa anos, findos os quais ele voltaria para ver como estava a coleção. Se estivesse bem, assinaria a doação final... Eu espero que a minha participação - e a dos colegas da mesa, que foi muito boa - ajude José a se convencer de que ela está em boa casa.

Coisas muito interessantes foram ditas por Calil, que me antecedeu. Como sempre nessas situações, as conversas de corredores antes da sessão são muito interessantes. Aqui hoje, na plateia, estão uma ex-diretora da Biblioteca Mário de Andrade, Cristina de Almeida, e o atual diretor da Biblioteca, Charles Cosac. Com eles estávamos conversando sobre situações mais ou menos análogas àquelas que o Calil expôs aqui e certamente se eles pudessem reproduzir para este público a conversa que tivemos, todos sairíamos ganhando. De todo modo, vou dedicar-me a ponto um pouco diferente dos abordados pelos outros diretores aqui presentes e por Calil. Não sendo um especialista em conservação, nem em bibliotecas, apesar de ter vivido a maior parte da minha vida universitária em um departamento que se dedica a isso, entendi que minha apresentação de hoje poderia derivar de um grupo de estudos que eu coordeno agora no Instituto de Estudos Avançados, grupo que se volta para as culturas computacionais, essas que já estão à nossa volta. Como essas culturas já estão bem implantadas entre nós, não apenas meu grupo deveria estar atento a elas como toda a sociedade, e que nesse momento, deveria estar preocupada com o que está pela frente - que na verdade já está bem instalado entre nós. A conversa que manterei com vocês tem uma marca muito prospectiva. Não se volta para trás, não é retrospectiva. O papel prospectivo é o papel que cabe à ciência. A ciência é o instrumento do conhecimento humano capaz de antecipar as questões que aparecerão daqui a pouco. Lembro-me, dos meus estudos do colégio, e talvez vocês também, da Tabela Periódica de Mendeleiev, tabela de elementos químicos que possuía espaços vazios reservados aos elementos que ali deveriam figurar mas que ainda não haviam sido identificados, embora a teoria dissesse que ali, naquelas casas vazias, deveriam estar. Naquele momento em que eu estudava a Tabela de Mendeleiev, ela era um queijo suíço, com um monte de espaços vazios e apenas alguns tantos elementos químicos. Recentemente eu revi a Tabela de Mendeleiev e ela está completamente lotada, não tem vaga para mais ninguém. Esse é o sinal mais forte da presença de um procedimento científico. Ciência é a capacidade humana de prever o que vai acontecer, e de organizar-se para enfrentar o que vai acontecer. No nosso campo das Humanidades é um pouco de soberba, de arrogância, dizer que temos condições de praticar esse tipo de ciência. Mas temos que tentar, com o que está à nossa disposição. O grupo de estudos dedicado às culturas computacionais 
tem exatamente essa preocupação: estudar o que já está aqui e ver o que podemos extrair disso de modo a nos prepararmos, na universidade, para renovar cursos e linhas de pesquisa e não ficar o tempo todo olhando apenas para o passado. O que farei aqui é apenas um resumo muito forte do que, a rigor, deveria discutir hoje com vocês.

Estudar as culturas computacionais hoje em dia é uma tarefa de Sísifo. Há dezenas, centenas de casos de culturas computacionais, cada um com suas propriedades, seus efeitos e modos de participação. Fazer apenas uma lista do que existe não é ciência. A lista, no máximo, com boa vontade, é um estado juvenil da ciência. Alguém é capaz de ver o que está acontecendo, de elencar aquilo que observa. Já está bem, mas não basta, é preciso transformar essa lista em algo que permita ver o quadro geral de uma maneira realmente germinadora. O que permite fazer isso é a detecção de uma estrutura orgânica daquilo que se está estudando. E assim foi que me dediquei a tentar encontrar uma estrutura das culturas computacionais, daquelas que estão aqui agora e das que possam vir pela frente. Um colega físico, que faz parte do nosso grupo, tem um problema com a palavra "estrutura”. Ele a considera uma palavra muito complicada, apesar de todos esses anos do estruturalismo, que causaram uma grande mudança na abordagem da antropologia e da cultura em geral. Então, em homenagem ao colega físico e para evitar problemas maiores, prefiro usar aqui a palavra "narrativa". O que eu vou fazer é uma narrativa de alguns traços dessas culturas computacionais, dos quais selecionei alguns que tem mais relação com o tema desta mesa, o das bibliotecas, da conservação, da leitura, mesmo que não os trate diretamente. Identifiquei cerca de vinte desses traços, mas vou abordar aqui apenas meia dúzia deles que considero mais significativos. É um exercício intelectual que proponho, pois este é um trabalho em progresso, ainda não é um livro ou uma tese final.

A cultura computacional é, basicamente, automação. Cada vez mais presente em todos os aspectos da nossa vida, a automação tem um aspecto muito peculiar, ao meu entender um de seus efeitos mais agudos: o afastamento do ser humano de todas as atividades com as quais estava envolvido. De praticamente todas elas. Não se trata apenas do motorista de táxi, que daqui a pouco será colocado de lado porque os carros se conduzirão a si mesmos, mas também do professor universitário, do bibliotecário, eventualmente mesmo de um restaurador. A automação está acelerando violentamente a substituição do ser humano pela máquina. É o que acontece nas montadoras de veículos, por exemplo. Hoje as atividades da cultura empregam mais gente no Brasil que a indústria automobilística. E não há muita surpresa nisso, pois a quantidade de robôs que existe nas fábricas de qualquer marca de carros é enorme, uma 
única pessoa pode controlar dezenas de equipamentos e ser, no limite, responsável pela produção de vários veículos. Os seres humanos estão saindo de cena, e não apenas na produção industrial. Tenho alguns dados particularmente preocupantes. Cinco pessoas ainda são necessárias para que a Walmart venda um milhão de dólares em produtos. A Amazon, por ter-se automatizado num grau elevado, emprega uma pessoa a cada milhão de dólares em produtos vendidos. E o problema é que a Amazon está cada vez mais vendendo os mesmos produtos que o Walmart. A Amazon comprou a cadeia de supermercados americana Whole Foods, rede de lojas diferenciadas, lojas boutiques como se diz hoje. E fico imaginando o que acontecerá quando a Amazon, além de tudo que já vende, instalar-se também nos supermercados, penso no que pode acontecer em termos de eliminação de vagas de trabalho, algo que já ocorre em São Paulo, na medida em que serão dispensados funcionários que orientam os consumidores, que cobram pela venda feita: em breve, o consumidor pagará ele mesmo pelo que estiver comprando, exemplo claro de como a cultura computacional vai tirar o homem de circulação. Há outros tantos exemplos mais claros. Um muito agudo e recente é o dos aviões. Espero que isso não assuste ninguém, se é que vocês já não sabem disso, mas hoje a maior parte das decolagens, do voo lá em cima e da aterrisagem é feita ou pode ser feita por computador, sem que o piloto faça coisa nenhuma. O piloto está lá de braços cruzados lendo um jornal, atento e servindo de alternativa caso algum problema aconteça. Vinte ou quinze anos atrás haviam três pessoas na cabine de comando de um avião: o navegador, que não é mais necessário por conta do GPS e tantas outras coisas, o piloto e o copiloto. Hoje há dois, mas as empresas aéreas querem colocar apenas um, preparando nosso espírito para quando não houver nenhum. Um estudo recente da Oxford University prevê que num período entre cinco e dez anos 47\% dos empregos atuais vão desaparecer. Os nossos empregos, aqui na universidade, estão dentro desses $47 \%$ ? E $47 \%$ é uma estimativa conservadora, pois dados mais atuais falam em $50 \%$ : a diferença parece pequena mas se estivermos envolvidos nesses 3\% a mais a situação fica complicada, não é mesmo? A automação crescente é uma realidade, inclusive em nossa área de atuação profissional.

Outro traço, fortemente ligado às questões de conservação é o da impermanência. Em outras palavras, o desaparecimento da matéria, a virtualidade extremada. Recentemente na Inglaterra, em 20 de junho deste ano, a primeira-ministra Theresa May ganhou mal as eleições que ela mesma havia convocado, acreditando que o povo a colocaria lá em cima, e no entanto apenas conseguiu manter uma pequena maioria no Congresso. No início do novo governo, que no entanto era o velho governo, como sempre, a rainha Elizabeth, ou quem estiver no seu lugar, tem 
de fazer um discurso de apresentação do novo programa. Todo discurso real tem de ser primeiramente escrito em um pergaminho especial, com uma tinta especial, para que o documento dure pelo menos quinhentos anos. A rainha Elizabeth, como tudo indica, vive em um outro mundo e outro tempo. Comparem a permanência de seu discurso escrito com qualquer outra coisa que conheçam. E nem abordarei aqui, pois vocês sabem disso melhor que eu, os problemas dos atuais suportes da informação quando o que está em jogo é sua duração no tempo. Todos nós sabemos como o hardware, o próprio equipamento, não só o software, muda. Comecei minha carreira acadêmica pouco antes do aparecimento dos floppy disks maleáveis. Tenho centenas deles em casa, com os quais não posso fazer mais nada. O próximo passo foi o disquete pequeno, quadradinho, do qual vocês se lembram. Idem. O passo seguinte foi o CD. Idem. Agora tenho um pendrive, como todo mundo tem. Qual a durabilidade disso? Qual a durabilidade da informação nele contida? E antes do computador eu escrevia à máquina - não sou do tempo em que se escrevia à mão - e produzia aquilo que recebia o nome de originais. Não existe mais o original, no sentido físico do termo. O escritor contemporâneo, quando esgota seu veio de criação e nada tem mais tem a vender, não mais pode considerar vender seus originais, como fazia o escritor moderno e os que o antecederam e que escreveram, todos, à mão. O que o escritor contemporâneo tem ou teria para vender é uma coisa anônima, sem cheiro, sem gosto, sem nada, sem consistência, sem materialidade: ele não tem nada, tem um arquivo digital que não traz as marcas de suas correções, nem a do copo de vinho que talvez tenha pousado sobre uma página, nem mesmo vestígios de seu DNA que impregnaram o papel onde escreveu. Essa é a impermanência, outra narrativa das culturas computacionais, ao lado da automação. O ser humano é tirado de cena em quase todos os aspectos, como no campo das relações humanas. Os call centers de hoje, vocês sabem, não usam mais pessoas para falar com você. Estão aprimorando, na melhor das hipóteses, o sistema de voz, como se diz, em que você escolhe alternativas. Quando você insiste, depois de vários minutos, em falar de fato com alguém, esse alguém não sabe resolver o seu problema...

Uma terceira narrativa das culturas computacionais é a desintermediação. Em choque frontal com a área da universidade, de bibliotecas e do ensino. No século passado, por volta dos anos 1980, eu costumava dizer que a era dos explicadores estava acabando. Aquele era o último século dos explicadores, que eu não chamava de intelectuais, porque talvez na segunda metade do século xx os intelectuais já estivessem um pouco... desaparecendo. O momento dos intelectuais foi até a primeira metade do século xx, depois tenho a impressão de que sobraram 
apenas os explicadores. Mas também os explicadores estão sumindo e vão sumir. O que nós temos hoje é, efetivamente, uma situação tal em que todos aqueles que ficavam entre a fonte (da informação, do conhecimento) e o receptor estão desaparecendo e sendo substituídos pela máquina. Há centenas de exemplos disso. Vamos começar pelo livro. Todo mundo aqui já leu, ou já viu o filme Cinquenta Tons de Cinza ou já ouviu falar dele. (Não há problema nenhum em admitir que já leu ou livro ou viu o filme, já superamos essa etapa da moralidade... por enquanto, em todo caso: a civilização sempre se esquece de suas conquistas e está condenada a refazer seus passos em muitos aspectos...). Cito a série de livros de E. L. James porque ela é um exemplo perfeito da queda quase irreversível do processo de mediação que foi a produção do livro até bem recentemente. Essa autora escreveu o livro no computador, colocou-o na internet e fez um sucesso estrondoso por conta própria. Só depois uma editora apareceu e fez um contrato para colocar o livro dela em papel. Depois vieram os filmes e tudo mais. Nesse caso, todas as intermediações entre o escritor e o leitor foram, no mínimo, condensadas. Cada uma das quatro fases do sistema de produção cultural - produção, distribuição, troca (geralmente, na nossa sociedade, requerendo o dinheiro) e uso efetivo do bem produzido - tem seus problemas. Como produzir e, se for o caso, quais são os subsídios para a produção; como distribuir; como ter acesso ao bem produzido; e, uma vez tendo o livro na mão, como de fato apropriar-se daquele livro, tornar subjetivo aquilo que está lá incorporar esse conhecimento. Antes, quando alguém queria escrever um livro, precisava vencer uma primeira barreira, a da edição. O editor era (e continua sendo) o primeiro e grande crítico literário: "seu livro eu aceito, seu livro eu não aceito”. Hoje o autor não precisa mais passar por esse crivo. Depois de publicado, o livro precisava ser distribuído. Fisicamente. Como distribuir um livro no Brasil, com as pouquíssimas livrarias que existem, e que existem cada vez menos? Agora, não há mais esse problema, pois a distribuição é feita pelo próprio computador e quase todo mundo tem um computador ou tem acesso a um. Às 11h59min eu leio em um jornal digital estrangeiro que saiu um livro fantástico da minha área, às 11h59min30s eu faço o pedido do livro e pago por ele, à meia-noite o livro está comigo, à 0h1min já estou lendo aquele livro. A etapa de intermediação da distribuição sumiu. A troca é hoje amplamente facilitada desde que você tenha algum dinheiro. Há uma tendência, por enquanto, de que o livro digital custe um pouco menos do que o impresso, o que daqui a pouco talvez se altere. Mas a antiga cadeia de intermediação tende a desaparecer. Idem no cinema. Antigamente você filmava, revelava o filme e o transformava em uma película em seguida 
acondicionada em latas, as latas tinham que ser postas no caminhão, o caminhão levava até a distribuidora - se ela aceitasse aquele filme - e a distribuidora entregava aos cinemas, se eles quisessem aquele filme. Isso acabou. Você grava o filme (não há mais uma fita física), coloca o filme diretamente na internet e o distribui para uma rede de cinemas. A intermediação está desaparecendo. A detenção de uma fonte de informação pelos explicadores também está desaparecendo. Se você está conversando com amigos e tem uma dúvida sobre qual foi o ano em que algo foi feito, quem fez o quê, você tira do bolso ou da bolsa esse instrumento que nós temos aqui na mão [um celular] e resolve o problema. A intermediação sumiu de quase todos os aspectos em que vocês queiram pensar. Até mesmo do diagnóstico médico. Há máquinas que fazem diagnósticos completos. O Dr. House, da série de televisão homônima, vai perder o emprego - e nós, o filme em que ele aparece... Não mais se requer, a rigor, um ser humano para fazer um diagnóstico, a máquina faz isso - e ela pode mesmo operá-lo. A desintermediação é outra das narrativas centrais do novo tipo de cultura que estamos vivendo.

Há também a individuação. Sobretudo no século xx, que é o grande século de difusão, de cultura de massa etc., tudo o que nós fizemos foi trabalhar para - como dizem as empresas de marketing e publicidade segmentos da sociedade. A ideia de segmentos está desaparecendo, porque é possível hoje atender, tocar, acionar as pessoas individualmente. Como vocês devem estar sabendo, ainda que não tenha sido o determinante, um dos fatores que contribuiu para a eleição de Donald Trump foi o fato de duas empresas terem, uma, 240 milhões e outra, duzentos milhões de perfis de norte-americanos cujas preferências passaram a conhecer e com os quais podiam falar diretamente, um a um. Obviamente em algum momento esses dois números não se somam, se sobrepõem, mas a quantidade de pessoas é incrível. Essa quantidade enorme de informação possibilitou que nos dias finais da campanha Trump comprasse todo o tempo disponível no YouTube e veiculasse anúncios específicos para lotes reduzidos de pessoas. Você não ia votar no Trump porque ele é racista? Tem um vídeo para isso. Porque ele é contra o Estado? Tem um vídeo para isso. Nós nunca encontramos antes essa situação. E a individuação se espalha para outros campos, em alguns países mais do que outros, conforme o grau de sofisticação ou modernização tecnológica. Pense, por exemplo, no caso das roupas. Aqui no Brasil nós ainda compramos roupas - falarei das roupas paraem três ou quatro tamanhos. Pequeno, médio, grande e extragrande. Nos Estados Unidos, você entra numa loja de roupas e encontra três ou quatro medidas de cintura que se combinam com três ou quatro comprimentos de perna, de tal forma que é praticamente impossível 
você sair da loja sem uma calça que sirva. A menos que você esteja completamente fora do quadro - mas aí é problema seu, não da loja. E não há ninguém para fazer a bainha da calça ou do paletó, porque há um tamanho de paletó para você. Mas isso é pouco, daqui a dois ou três anos a loja fará na hora o terno para você. Não sei se é possível imprimir um termo em 3D, mas sei que é possível imprimir um coração, então deve ser possível imprimir uma calça. Como isso pode projetar-se no campo da cultura? Antes, nós, escritores, diretores, produtores de filmes, fazíamos filmes para segmentos definidos. Não vou dizer nem predizer que o segmento irá desaparecer. Mas é claro que podemos prever, como possibilidade, produtos culturais para o um, para um indivíduo. Podemos aqui abrir um parênteses para falar de coisas das quais não se deve falar; mas, o fato é que um livro bom, de alta literatura, que realmente valha alguma coisa, não foi feito para um público, foi feito para o próprio escritor, para o um. Ele faz aquele livro porque precisa daquele livro, que está descobrindo enquanto o escreve. Vamos citar Finnegans Wake, que James Joyce levou 21 anos para escrever, ou mesmo o Ulisses, que consumiu catorze anos de sua vida. Vocês que já leram o Ulisses sabem que é difícil, e vocês que já tentaram ler o Finnegans Wake e não conseguiram, sabem que essa é uma missão quase impossível. James Joyce o leu. Haroldo de Campos também, ele que traduziu um capítulo do Finnegans Wake... O fato é que um livro bom é para o autor, para um. Não é impossível que daqui a um tempo possamos fazer livros e filmes para um. Quando falei da desintermediação, esqueci de mencionar o exemplo da Netflix, com todas suas consequências sociais - estou falando de convivência na sociedade, não de ideologia propriamente. Lembro-me que íamos em quatro, cinco amigos ver La Dolce Vita no Cine Coral, na Sete de Abril. E depois íamos para um bar discutir o filme. Agora eu vejo La Dolce Vita, ou equivalente, à meia-noite, em casa, sozinho, enquanto meu amigo está vendo outro filme ou nada. Isso é um exemplo de desintermediação e individuação. O filme apenas para você ainda não existe ${ }^{1}$, mas você é senhor do seu tempo e do seu consumo cultural. Qual é a consequência disso no campo das bibliotecas, por exemplo?

A unificabilidade é outra narrativa extremamente relevante das culturas computacionais. Tudo converge para o um. A espécie humana, até agora, existiu por causa da diferenciação. Nós estamos aqui por conta disso. Eu não sou da área, mas sei que aquelas bactérias, foram

1. Faço a revisão deste artigo em fevereiro de 2019 e o filme Bandersnatch, na Netflix, da série Black Mirror, já é um filme quase individual, quase para o um uma vez que o Bandersnatch que vejo pode não ser aquele que você viu... (Teixeira Coelho) 
diferenciando-se e aqui estamos nós. E depois fomos nos diferenciando em termos de sociedade. Em 2005, a diversidade tornou-se um valor defendido pela ONU, pela Unesco, estamos vivendo esse processo. Mas as culturas computacionais tendem à unificação. Pensem em coisas muito simples: vamos supor que você pertence à fatia ainda relativamente restrita dos que têm um carro. Até pouco tempo atrás você precisava ter um telefone e um tocador de fita e um relógio e um gravador pequeno e um GPS para localizar-se. Hoje todos os cinco ou mais aparatos diferentes estão reunidos no celular. A propensão das culturas computacionais é fazer tudo convergir para uma coisa só e tudo tornar indissociável. As consequências políticas e ideológicas disso são enormes, além das existenciais, das quais cada um de nós já tem uma ideia pois já está vivendo isso. O Estado quer sempre ser um, como sabem aqueles que viram filmes do Jean-Luc Godard. É mais fácil governar se todos os duzentos milhões pensarem e consumirem as mesmas coisas. Esperava-se que isso se tornaria mais difícil com a internet, que ela levaria a democracia para todos os lados. Mas vejam o que está acontecendo com a China, que dá belos exemplos de como é possível, sim, controlar a internet, inclusive com a cumplicidade da Google, que, muito interessada no mercado chinês, está se dobrando às exigências censórias de seu governo, que já tem a possibilidade de bloquear o Facebook, o Twitter e tudo aquilo que não quiser. Então, o que vai convergir para a unificabilidade e quem vai controlar tudo isso?

Falemos da combinatoriedade. No campo das culturas computacionais, quase tudo pode ser combinado com quase tudo, por critérios os mais diferentes e imprevisíveis. Por exemplo, o sistema de armazenamento de livros da Amazon não segue, até onde sei, os sistemas tradicionais da Biblioteconomia. Os bibliotecários podem classificar livros por autores, assuntos, etc. Já a Amazon estoca livros pela frequência com que eles são comprados e se são comprados juntos, aos pares ou trios, ou não. E não não se trata de poupar o tempo da pessoa que vai buscar esses livros no estoque, porque é o computador que vai lá pegar esses livros. Isso, no começo, era chamado de lógica caótica. Meu amigo físico tem chiliques quando conversamos sobre isso. A lógica caótica é aquela que não nos é acessível, cuja chave nos parece fora de alcance - ilógica. A Amazon também estoca livros pelo tamanho, o que é muito mais racional em termos de espaço. Eu tenho esse problema em casa e adoto essa solução em casa há tempos, meus livros já são há muito estocados por tamanho, não por nenhuma lógica, mas pelas condições físicas da minha estante: neste espaço cabem os livros maiores, neste outro os de bolso e assim vai. O caos se instala, não acho mais nada. Mas a Amazon, com computadores, acha... Não imaginava que a Amazon copiaria meu sistema patenteado... Então, estamos nós preparados para uma situação em que quase tudo pode 
ser combinado com quase tudo e de muitos modos, se não de qualquer modo? Quase tudo pode ser representado pela lógica digital enquanto ela continuar vigorando: o quântico já bate à porta, mas ninguém sabe ainda muito bem como funciona, ninguém conseguiu criar uma máquina quântica confiável ${ }^{2}$, muito menos economicamente acessível. Na lógica digital, tudo pode ser traduzido para zeros e uns. Traduzo um livro em uma sucessão de zeros e uns, assim como uma música, um quadro. Aquilo que antes era chamado, na melhor das hipóteses, de correspondência entre as artes, encontrou agora um modo físico de expressar-se. Havia um ramo da Filosofia Estética que tratava disso: a literatura pode conversar com a música? A música pode conversar com a arquitetura? Talvez alguém aqui tenha lido o filósofo Étienne Souriau, que se dedicou a isso. Mas com a lógica digital, tudo corresponde-se com tudo. Eu posso transformar um livro em zeros e uns e ver os desenhos formados. Nós ainda vivemos em um mundo de compartimentos herdados do Iluminismo do século XVIII. A separação em gavetas foi um grande avanço da humanidade, quando comparado àquilo que havia antes, a convergência de tudo para o um, convergência que nos séculos anteriores se dava na Igreja. Não havia arte nem ciência, e sim a arte e a ciência que cabiam à religião. Tudo era uma coisa só, algo que o Iluminismo separou: a arte passa a correr aqui, nesta trilha, a ciência por aquela, a religião por aquela outra. Pois estamos entrando em um outro período, em que as coisas tendem outra vez a recombinar-se num só. E combinando-se, tendem a convergir ${ }^{3}$. Como isso pode se refletir numa situação de bibliotecas.

Há também a possibilidade de duplicação. Walter Benjamin escreveu o texto que se transformou em uma bíblia para todos os estudantes de estética, filosofia, sociologia, A Obra de Arte na Era de sua Reprodutibilidade Técnica. Acabamos de entrar definitivamente na época da reprodutibilidade, na época da Grande Reprodutibilidade, tudo pode ser reproduzido. O caráter de coisa única, portanto de coisa valiosa porque única, desapareceu. Posso fazer uma réplica da Monalisa em todos os aspectos, inclusive sensoriais. A ideia da originalidade e do valor do único desaparece totalmente. O livro raro, a partir de um determinado momento, não existe mais. A ideia da obra rara, única, singular, não existirá mais. Nossos valores serão alterados em relação a isso.

Para terminar abruptamente essa lista, que de fato continua, posso pensar também em um tema que andou muito em voga nos anos 1970, 1980, sobretudo com Michel Foucault e Roland Barthes, o tema

2. Agora, em fevereiro de 2019, já há alguns à venda... (TC).

3. Só que, como no conto de Borges Pierre Ménard, Autor de Quijote, a recombinação nunca reproduz o mesmo sentido anterior... (TC). 
da "morte do autor", etc. O anonimato, ou a indiferenciação da fonte. Que é autoria? Autoria é acesso à informação? Capacidade de produção? Capacidade de edição? Aliás, a editabilidade é também uma outra propriedade das culturas computacionais. Hoje você pode editar até mesmo seu DNA. Bem recentemente uma cientista foi capaz de encontrar um meio de cortar um pedacinho minúsculo de DNA e trocá-lo por outros. Mas voltemos à autoria. O teorema que eu gostaria de ver provado um dia é o seguinte: à medida que você aumenta o acesso à informação, a capacidade de edição e a capacidade de produção, a autoria tende a desaparecer. A indiferenciação tende a aumentar. Sei que o termo "anonimato" é radical, mas ele tende a se instalar. E com o anonimato, a obra cultural, o livro, o filme para um tendem a se tornar realidade.

Escolhi aqui alguns dos vetores da cultura computacional. As mudanças que representam já estão acontecendo e não estamos percebendo. Ou não estamos querendo perceber. Nós não queremos perceber, por exemplo, que o professor está com seus dias contados. Tradutor já não há mais, a rigor. Ou desaparecerá amanhã pela manhã. Se você quiser traduzir um texto do inglês, o tradutor da Google está muito bom, é alterar talvez 10 ou $20 \%$ do resultado dado pela máquina. Ele não traduz bem francês ou italiano, mas inglês sim, bastante bem, pelo menos o inglês simples. O tradutor está desaparecendo. Estou radicalizando, mas não muito. O professor também está sumindo, o condutor de veículos também. São essas pequenas narrativas, comuns a todo um espectro das culturas computacionais, que deveriam nos alertar para aquilo que vai se instalar e para nos convocar para uma renovação de nossas perspectivas e de nosso modo de trabalho. Isso quer dizer que a biblioteca vai extinguir-se amanhã, no fim do ano, daqui a cinco anos? Não, pois a preservação, de alguma maneira, supõe-se, continuará existindo. Como a preservação e a conservação podem dar-se, se serão alterados os conceitos de raridade e autoria? São essas as questões que selecionei para comentar com vocês, essa era a contribuição ${ }^{4}$, se o for, que podia fazer para esta mesa de debates. Obrigado.

4. Neste momento, fevereiro de 2019, já está pronto o livro do qual a palestra aqui transcrita, pronunciada na Biblioteca Brasiliana Guita e José Mindlin, foi um embrião. Sob o título eCultura, A Utopia Final (Inteligência artificial e Humanidades), será publicado em abril de 2019 pela Editora lluminuras. (TC)

\section{SOBRE 0 AUTOR}

Escritor, professor emérito da USP, é pesquisador junto ao IEA-USP. Foi diretor do MAC-USP, curador-coordenador do MASP e diretor do IDART. Publicou, entre outros, Dicionário Crítico de Política Cultural e A Cultura e Seu Contrário. Próximo livro neste campo: eCultura, a Utopia Final (Inteligência artificial e Humanidades), junho de 2019. Autor de romances, entre eles História Natural da Ditadura. 


\section{A CULTURA EM PROCESSO DE MUDANÇAS EXTREMAS}

RESUMO $\mathrm{O}$ artigo aborda as culturas computacionais, essas que já estão à nossa volta, em diversos âmbitos sociais, desde multinacionais a best-sellers. Como essas culturas já estão bem implantadas entre nós, o autor defende que a sociedade deve estar atento a elas, já que o que já está instalado entre nós diz muito sobre o que vem pela frente. Desse modo, o artigo mantém com o leitor um diálogo prospectivo. Não se volta para trás, não é retrospectiva. O papel prospectivo é o papel que cabe à ciência.

CULTURA - COMPUTACIONAL • AUTOMAÇÃO • SOCIEDADE.

\section{CULTURE IN THE PROCESS \\ OF EXTREME CHANGE}

ABSTRACT The article addresses the computational cultures, which are already around us, in multiple social spheres, from multinationals to bestsellers. As these cultures are already well established among us, the author argues that society should be aware of them, since what is already consolidated demonstrates a lot about what lies ahead. Thus, the article maintains with the reader a prospective dialogue. It does not turn back and it is not retrospective. The prospective role is the role of science. CULTURE - COMPUTATIONAL • AUTOMATION • SOCIETY. 